\title{
Children's Evaluations of Villains in Children's the Heroes and Literature
}

\author{
Panagiota Spanothymiou ${ }^{1}$, Argiris Kyridis ${ }^{1}$, Anastasia Christodoulou ${ }^{1}$, Meni Kanatsouli ${ }^{1}$ \\ ${ }^{1}$ Aristotle University of Thessaloniki, Greece \\ Correspondence: Anastasia Christodoulou, Faculty of Philosophy, Aristostle University of Thessaloniki, Greece.
}

Received: March 12, 2015 Accepted: March 27, 2015 Online Published: April 21, 2015

doi:10.11114/smc.v3i1.779

URL: http://dx.doi.org/10.11114/smc.v3i1.779

\begin{abstract}
Literature plays a key role in shaping values, its foremost albeit controversial element being the concept of the hero. The hero, a central sign in the tale, leads readers towards many codified readings. It is a concept invested with a number of different semantic and value loads. With this in mind, this study aims to explore the value judgements made by children with regard to the literary heroes and heroines found in their narratives (stories and films). It is a study of ninety-seven children in the sixth year of primary school, from two urban centres in Greece, namely Veria and Thessaloniki. The children were asked to anonymously fill in a questionnaire, which included ten questions related to their favourite and least-liked heroes and heroines and an assessment of their preferences. The study aims to identify the traits that children use to signify literary heroes and heroines. The results indicated that the readings are codified with interesting elements related to the concepts of good and evil, beautiful and ugly.
\end{abstract}

Keywords: children evaluation, heroes, children's literature

\section{Theoretical Aspects}

Literature has always been a significant source of role models. The role models it promotes, establishes and utilizes are so strong that they are adopted by other channels of communication, such as television, the press and electronic games. Heroes are also used in the classroom as a form of educational intervention, so as to encourage children's emotional and moral development. Heroes and role models could thus be studied in terms of the system of values and convictions that they represent, with the aim of exploring them further (Gavriilidou, 2008; Gkolia \& Kyridis, 2008; Kouraki, 2008; Hogan, 2004). Very similar to the role model addressed by literature is the theory of the "narrative paradigm" that proposed by Walter Fisher (1985a, 1985b, 1989). Fisher stressed out that every social person encapsulates life and its own being as a context of ongoing narratives of every form. At the same context every child sees his life and his dreams within the narration which literature provides.

The concept of the hero in literature fascinates readers through the emotional, ideological, conceptual and other loads it carries. In the learning process, literature helps to nurture the imagination and build new meanings. However, there lurk unforeseen risks in the manner that heroes as role models affect children's behaviour (Lockwood, et al. 2002; Lockwood, et al. 2004). While role models may be a positive inspiration, there is also the risk that they will limit the reader's personality, encourage certain ideas, prescribe behaviour and subject the reader to specific rules and emotions.

It is generally agreed that a hero or heroine, as a person who bears value characteristics, adopts and reflects humanity's highest expectations. The hero or heroine is thus a source of inspiration and a guide for individuals and society, who can identify with him or her more easily if the hero or heroine resembles an ordinary, everyday person (Nikolajeva, 2002: 22-23; Platsidou, 2001: 147-155; Campbell, 1968). Of course, the extent to which the hero or heroine is imitated or identified with differs from child to child, depending on the value models that a child has internalized and on how much the child admires that particular hero or heroine (Gkolia \& Kyridis, 2008, Papantonakis, Athanasiadis, Kaplanoglou \& Politis, 2010: 101-138; Duck, 1990; Knapp, 2003).

According to the proponents of moral education, the use of heroes as an educational medium can be a useful tool in teaching moral behaviour (White \& O'Brien, 1999:81-95). Erikson has a positive view of the role that heroic role models play in children's psychological development, since children then learn from a young age to play parts or act out stories that contain altruistic behaviour, brave feats and integrity (Platsidou, 2001).

A hero could be described as a person with widely accepted moral behaviour, who goes beyond personal interest, does not tolerate injustice and keeps their word (Platsidou, 2001). Heroes, as cultural models and popular and symbolic 
figures, encourage the masses to meet social goals. Heroes are able to play these roles because of the value characteristics they bear, which urge the hero to achieve the desirable social goals and bring about change (Jones \& Watkins, 2000: 1-19; Platsidou, 2001: 57-70; Brunel, 1992).

Naturally, a writer chooses the character of their story's hero with certain goals in mind. On one level, the hero's goal is to intervene and steer the plot, while on another level their goal is to bring to the fore experiential situations, cultivate a conscience, determine behavioural limits and create or evoke emotions. Thus, a character will form their own, unique world of values which stems from the interaction with other characters on two semantic structural levels, the paradigmatic and the syntagmatic axes (Greimas, 1966).

Of course, for a story to be entertaining, believable and interesting, it needs characters that propel the story forward. It is, however, often believed that the characters in children's narratives cannot be fully developed or complex. There is the conviction that children do not possess the necessary experience or knowledge to understand the moral, intellectual or mental changes that a character undergoes, so we need to contrast them with strengths and shortcomings in order to avoid monosemous knowledge. The relationship and association between characters is a central point around which the type of story will be built.

The hero undoubtedly plays an important role in the plot's unfolding and in all the textual functions. The character exists in the plot as an integral part of the narrative, without it being certain if and when the events guide behaviour or in what way and to what extent the character influences the events. In other words, there develops in the narrative a polysemous interaction between events and characters for no clear reason (Nikolajeva, 2002; Nodelman \& Reimer, 2003).

There are thus different plots in a narrative. In a cumulative plot, the entry of each new character or event signifies, as a narrative device in children's works, a linear correlation between the characters. An element of signification in the narrative is the hero's name code, which is of vital importance from the moment the narrative begins. In the course of the narrative, the hero's name semantically acquires a number of positive loads. Consequently, by the time the narrative ends, the name code will have been transformed into a fame code. The hero's name is often included in the title and is, together with the cover illustration, an initial means of determining his traits (Gavriilidou, 2008:148).

In children's books the title is usually simple, understandable and brief, and lacks any double meanings or complex codes. It embodies a simple commerciality to make a book more easily chosen and purchased. The title's purpose is thus to provide a brief conceptual representation of the entire scenario, or part of it. It has been noted that the customary technique of including the hero's name in the title makes it easier to associate the protagonist's name with that of a hero. Peter Pan, Alice in Wonderland, Pinocchio, Tom Sawyer, Huckleberry Finn and Harry Potter are some examples of a story's hero or heroine whose name also appears in the title (Gavriilidou, 2008:154).

Of course, inside the book, in the literary text's storyline, an idea is promoted using simple conceptual techniques which initially help the child to better understand the plot. This, rather than steering the reader in a predetermined direction, gives the child the freedom to choose the degree to which he or she will connect the idea with the storyline and the hero (Kanatsouli, 2008:237-242; Applebee, 1978; Wells, 1986). The characters that are part of the storyline have different roles, namely that of the hero, the assistant, the sender and the anti-hero, characters that interact at a narrative, surface level of meaning structures as well as at a deep structural level that will construct the ideology (Greimas, 1966).

The functions of the characters in a narrative naturally vary, but do not escape the confines of their predetermined roles. The variance is noted only in the different semantic loads that a character bears in a particular narrative. Thus, a classic, possibly archetypal, hero will appear to want to go against social conventions, but will also champion values such as friendship, generosity or self-sacrifice (Gavriilidou, 2002: 55-67; Campbell, 1968). The framework within which the story unfolds is an accessible environment for children and prescribes the different semantic loads of the various roles (Franz, 1997). This structural function results in the heroes being loved by children, making them interested in and sympathetic with their heroes' weaknesses and unforeseen actions, possibly because they recognize in the story something that they themselves would do.

Conceptions of heroes obviously vary based on a number of factors, one of which is age as the vehicle of experience. Thus, children of pre-school and early school age (five to six years old) semantically invest a hero with qualities and attributes that indicate he is a handsome and attractive individual, with exceptional natural or supernatural powers. Eight and nine year olds view a hero as someone who helps and does good things for his fellow human beings and society owing to a number of value characteristics, such as bravery, goodness and reliability (Huck et al. 2001). In early adolescence (eleven to thirteen years), a hero is someone who is brave, wise and good and is admired because of an important achievement or particular attribute, while fifteen to sixteen year old adolescents believe that a hero is an exceptional person known for his bravery, belief in moral values and self-sacrifice (White, 1999: 81-95). 
In other words, we note that an author's semantic investment of the hero is achieved in a specific structural manner, but it is unclear how children utilize this information. It is understood that the creators of children's stories consciously or unconsciously strive, through the narrative, to convey ideas that have particular associations for the authors; however, we do not know if these associations are internalized in the same way by children or whether they are read in the same way or differently, not at the narrative level, but at the level of connections and associations made (Sloan, 1991).

\section{Method}

It is true that children's language has a lot to tell us about their growth as human beings. Thus, in order for us to see children's codified readings regarding heroes, this study explores children's conceptions of the hero and the heroic models with which they identify (Martin, 2007).

We know that in every text there is a meaning potential that is always also defined by the environment in which it appears (Halliday 2004). The object of analysis was thus the semantic loads regarding the concept of the hero as children conceive it.

This study aims to record the traits that Greek children in their sixth year of primary school (aged $11-12$ years old, mean $=11.4$ y.o.) think of when they are asked to answer a series of questions on heroes in literature. More specifically, ninety-seven Greek schoolchildren were asked to state their preferences regarding their favourite and least-liked heroes and to state the extent to which they agree with twenty-seven statements about heroes and literary works. This particular age group was chosen because, based on Greek reality, (a) schoolchildren of this age read more literature in and out of school, (b) there are more books on the market for this age group and (c) having already read quite a number of books, these boys and girls are sufficiently able to recognize those elements that initially identify someone who becomes a 'hero' or 'heroine'.

The questionnaire that was used as a measuring tool to assess children's views of the attributes of heroes has ten questions. The first question concerns the respondent's sex, the second question is about where the child usually reads (at home, at the library, at school), the third question concerns the number of books read per month (none, one, two or three, three and above), the fourth question concerns when the child chooses to read (weekends, weekdays), the fifth question asks the child to name five of their favourite literary works, in the sixth question the child is asked to grade (not at all, moderately, very much, extremely) a number of traits (beauty, skills, mental attributes and physical attributes) of three of the literary heroes they like the most, the seventh question asks the child to grade (not at all, moderately, very much, extremely) a number of traits (beauty, skills, mental attributes and physical attributes) of three of the literary heroes they dislike the most, in the eight question the child is asked to name three much-loved literary heroes and to justify his/her choice, in the ninth question the child is asked to name three literary heroes $s($ he) dislikes and to justify his/her response and, lastly, the tenth question consists of twenty-seven statements for which the child has to state the extent of his/her agreement or disagreement (I disagree, I neither agree nor disagree, I totally agree). The twenty-seven statements in Question 10 are: (i) The heroes in literature have human attributes; (ii) I prefer supernatural heroes to human protagonists in books; (iii) Literary books are naïve; (iv) Literature underestimates us children; (v) I am always on the side of the villain in books; (vi) Villains in literature are more intelligent than the heroes; (vii) Literature gives us food for thought; (viii) Literature contains moral lessons; (ix) The heroes in films are simply lucky; (x) Literature does not benefit us in any way; (xi) The villains in books are more interesting; (xii) The stories are all similar; (xiii) In literature, I prefer the heroes to be imaginary beings; (xiv) I would like to be like the heroes in books; (xv) Literary heroes in no way resemble reality; (xvi) I would prefer it if the good guy didn't always win in literature; (xvii) Literature is more for adults; (xviii) Literature gives us knowledge; (xix) I laugh a lot with books; (xx) I want to do whatever I read in books; (xxi) I want the bad guys to become good in the end; (xxii) I like books that have imaginary countries; (xxiii) I want the heroes in books to all be children; (xxiv) My friends and I make believe that we are heroes from books; (xxv) At carnival, I dress up as the hero or heroine of my favourite book; (xxvi) I am tired of children's books; (xxvii) I want an animal just like the one my favourite hero or heroine has. A pre-test (12 interviews in order to construct the statements of the scale) and a pilot survey were conducted in order to verify the validity of the scale. Cronbach's alpha of the scale is $0.81(81 \%)$.

The answers were analysed based on a mixed model of content analysis (see Mucchieli, 1988; Moscovici, 1970; Weber, 1990; Neuendorf, 2002; Bardin, 1989) and socio-semiotic theory. In other words, both quantitative and qualitative data were assessed from the respondents' answers.

\section{Analysis}

Most of the respondents participating in the survey were girls (54\%) and a smaller number were boys (46\%). They prefer to read at home (94\%) than at a library, and prefer to do this at the weekend (75\%). Most children read two to three books a month (44\%), while a small number of children do not read any books $(8 \%)$. They have many favourite books and films, amounting to 109 titles. 
The analysis showed that children prefer heroes with mental attributes (48.9\%) (good, brave, cheerful, funny) and heroes with abilities (dynamism and bravery), rather than heroes with external beauty (1.4\%). From the children's perspective, most heroes are strong (16.1\%) and funny (15.6\%), and boys are preferred (74\%) (e.g. Nicholas ${ }^{1}$, Superman) to girls (26\%) (e.g. Alice, Pippi Longstocking). Most children choose their heroes from a low social class $(91 \%)$.

Taking a more detailed look at children's favourite heroes, we note that under the category of the hero there come a number of attributes related to beauty, abilities, mental attributes and physical attributes. Thus, from the 109 narratives mentioned by the children, a hero is: strong (Hercules, Robinson Crusoe, Batman, Peter Pan, Superman, Paperinik²), decisive (Aragorn), adorable (Tweety), quite handsome (Harry Potter), funny (Nicholas, Asterix, Obelix, SpongeBob, the Wimpy Kid, Pippi Longstocking, Constantina ${ }^{3}$, Donald Duck), brave (Hercules, Batman, Petros ${ }^{4}$, Jack Sparrow), invincible (the Magician of Samarkand), constant (Alice ${ }^{5}$ ), flexible (Tinkerbelle), active (Sinbad the Sailor), a good wizard or witch (Harry Potter, Hermione), mischievous (the Wimpy Kid, Nicholas), attractive (Superman), intelligent (Peter Pan, Nicholas, Superman), introverted (Batman), agile (Reepicheep), pleasant (Robinson Crusoe, Nicholas), adventurous (Alice, Nicholas, Constantina, Superman, Sinbad the Sailor), bold (Reepicheep), a blunderer (Nicholas), short (Asterix), tall (Superman), a vanquisher of evil (Harry Potter), an object of ridicule (Trigonopsaroulis ${ }^{6}$, the Dork ${ }^{7}$ ), friendly (Nicholas), rich (the Prince), beautiful (Sleeping Beauty), daring (Lucky Luke), cute (Tinkerbelle, Reepicheep, Minnie Mouse), a good character (Prometheus, Scrooge), capable (Obelix), kind-hearted (Harry Potter) (Table 1).

Of course, a hero can embody many semantic loads or meanings relating to physical attributes, abilities and beauty. For example, Nicholas is intelligent, pleasant, adventurous, funny, good and a blunderer; Batman is described as brave, tough and daring; Superman stands out for his strength, attractiveness, intelligence, beauty and height and Harry Potter for being a capable wizard, quite handsome, kind-hearted and for vanquishing evil.

Table 1. Distribution of statements referring to children's characterizations of heroes

\begin{tabular}{lll}
\hline & $\mathrm{f}$ & $\%$ \\
\hline Unclassified & 16 & 7.6 \\
Good/Evil & 31 & 14.7 \\
Brave/Dynamic & 23 & 10.9 \\
Happy/Cheerful & 7 & 3.3 \\
Funny & 33 & 15.6 \\
Strange & 4 & 1.9 \\
Mischievous & 6 & 2.8 \\
Decisive & 3 & 1.4 \\
Handsome/Cute & 14 & 6.6 \\
Strong/Active & 34 & 16.1 \\
Intelligent & 10 & 4.7 \\
Not very intelligent & 1 & 0.5 \\
Not very strong & 2 & 0.9 \\
Adventurous & 14 & 6.6 \\
Interesting & 8 & 3.8 \\
Sociable & 2 & 0.9 \\
Fair & 1 & 0.5 \\
Introverted & 1 & 0.5 \\
Sly & 1 & 0.5 \\
Total & 211 & 100.0 \\
\hline
\end{tabular}

As for the characteristics ascribed to a villain, there are more mental attributes $(48 \%)$ and fewer supernatural abilities $(2 \%)$. Villains bear a high number of negative or non-negative loads $(41 \%)$, while the concept of a villain is to a lesser

1 The protagonist of the series of children's books originally written in French by René Goscinny (French title: Le Petit Nicolas)

2 Also known as Superduck or The Duck Avenger

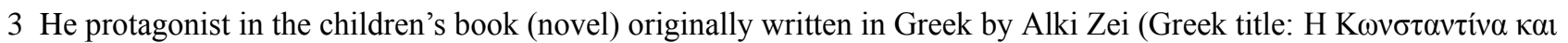

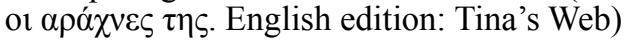

4 The protagonist in the children's book (novel) originally written in Greek by Alki Zei (Greek title: O $\mu \varepsilon \gamma \alpha \dot{\lambda} \lambda \varsigma^{\circ}$

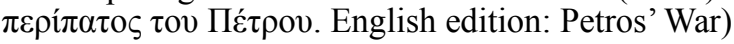

5 A protagonist in Jacqueline Wilson's Best Friends. All other references to Alice in this paper refer to Alice's Adventures in Wonderland by Lewis Carroll.

6 Trigonopsaroulis, meaning Triangle Fish, is the protagonist of a number of children's books written in Greek by

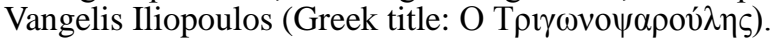

7 The protagonist of Rachel Renée Russell's Dork Diaries. 
extent associated with someone who is a know-it-all, a pain in the neck and funny (3\%) (Table 2).

Thus, a more detailed look at the semantic loads of the concept of a villain would reveal (s)he is: foolish (Trelantonis ${ }^{8}$ ), unpleasant (Trelantonis), an abductor (Cruella), funny (Goofy, Tweety, Scooby-Doo), ugly (Alice, the Pink Panther), naughty (Trelantonis), boring (Snow White, Batman, Tintin, Lucky Luke), a wizard (Harry Potter), strong (Hercules, Cerberus, Spiderman, Jack Sparrow), a girl (Barbie), a liar (the boy who cried wolf, Jack), intelligent (Spiderman, the Green Shark ${ }^{9}$ ), a cheat (Trelantonis), a villager (Farmer Percy Pickles), fat (Obelix), mischievous (Phileas Fogg), evil (the witch in Hansel and Gretel, Cruella, Cerberus, Blackbeard, Harry Potter, Scrooge), nervous/irritable (Gemma ${ }^{10}$ ), always the winner (Hercules), a know-it-all (Robin Hood), the one who tries to kill Harry Potter ('Mad-Eye' Moody), always asking easy questions (Dora), one who spreads evil and kills people (Harry Potter, Voldemort), a pain in the neck (Barbie), frightening to people (Cerberus), one who wears black (Batman), one without a cheerful face (Voldemort), not funny or entertaining (Bugs Bunny, Peter Pan, Tweety), not likeable (Sleeping Beauty, Mickey, Donald), one who wants to conquer the world by force (Voldemort), one who wants to eat the three little pigs (the Wolf), a smart alec (Bugs Bunny), one who says stupid things (Nicholas' friend), one who disguises himself (Tom Sawyer).

A villain can be characterized as such by means of a single description or a number of cumulative descriptions. The following are thus villains: Barbie, who is boring, vain, very stupid, a pain in the neck and a girl; Batman, who is boring and is for babies; Spiderman, who is strong, smart, defeats the bad guys, thinks that he beats them all, is handsome and casts webs; Tweety, because he thinks he is smart and entertaining; Voldemort, who is a villain because he wants to kill, cause chaos, conquer the world and does not have a cheerful face; Peter Pan, because he is neither entertaining nor funny; Superman, because he acts as if he is perfect, thinks he's a hotshot and pretends to be a tough guy although he is not; Trelantonis, who is a silly boy, cheats, is totally uninteresting, makes stupid blunders and is a pain in the neck; Harry Potter, who wears glasses, is evil, does magic, thinks he always wins and kills the strong wizard, and Snow White, who is boring and unadventurous.

Table 2. Distribution of statements referring to children's characterizations of villains

\begin{tabular}{lll}
\hline & $\mathrm{f}$ & $\%$ \\
\hline Unclassified & 9 & 9.2 \\
Evil & 40 & 40.8 \\
Funny & 1 & 1.0 \\
Strange & 4 & 4.1 \\
Mischievous & 3 & 3.1 \\
Strong/Active & 4 & 4.1 \\
Not very intelligent & 3 & 3.1 \\
Not very strong & 9 & 9.2 \\
Interesting & 1 & 1.0 \\
A know-it-all/Unpleasant & 2 & 2.0 \\
A liar & 6 & 6.1 \\
Boring & 14 & 14.3 \\
A pain in the neck & 2 & 2.0 \\
Total & 98 & 100.0 \\
\hline
\end{tabular}

It is quite significant that there is confusion among children regarding the semantic content of the concepts hero and villain. Thus, the analysis showed that many characters fall into both categories, in other words they are both heroes and villains. Some such examples are Barbie, Batman, Jack Sparrow, Superman, Tweety, Lucky Luke, the Wolf, Nicholas, the Little Prince, Obelix, Harry Potter, Catwoman, Alice, Aragorn, Cerberus, Constantina, Mickey, SpongeBob, Peter Pan, the Romans, Taz and Sleeping Beauty. In other words, some children have no fixed rating scale by means of which to clearly distinguish between a hero and a villain and, as a result, they place characters in both categories.

As regards children's preferences, it has additionally been observed that: (a) children mainly choose books with a happy ending (94\%), and also books with heroes rather than anti-heroes $(98 \%)$, (b) they prefer imaginary heroes to real heroes $(69 \%),(\mathrm{c})$ they choose books that are more serious $(74 \%)$ rather than humorous $(26 \%)$, (d) they choose books whose title indicates the hero's sex (59\%) and avoid books with a humorous title (8\%).

The above data concerns the first nine questions in the questionnaire. In the tenth question, the respondents were asked to state to what extent they agreed or disagreed (I disagree, I neither agree nor disagree, I totally agree) with twenty-seven statements made to determine perceptions. The data obtained from the tenth question are presented below,

\footnotetext{
${ }^{8}$ Trelantonis, meaning Crazy Anthony, is the protagonist of the Greek children's book (novel) written by Penelope Delta (Greek title: O T $\rho \varepsilon \lambda \alpha v \tau \omega ́ v \eta \varsigma)$

9 A protagonist of the children's book written originally in French by Jean-Loup Craipeau. (French title: A l'abordage, Mamadou courage!)

${ }^{10}$ A protagonist in Jacqueline Wilson's Best Friends.
} 
in Table 3, which shows the distribution of subjects' answers on a perception scale.

Table 3. Means and standard deviations per statement on the scale

\begin{tabular}{lcc}
\hline Statement (Question 10) & Mean & $\begin{array}{c}\text { Standard } \\
\text { Deviation }\end{array}$ \\
\hline (1) The heroes in literature have human attributes. & 0.723 \\
(2) I prefer supernatural heroes to human protagonists in books. & 1.91 & 0.771 \\
(3) Literary books are naïve. & 1.21 & 0.519 \\
(4) Literature underestimates us children. & 1.23 & 0.550 \\
(5) I am always on the side of the villain in books. & 2.23 & 0.823 \\
(6) Villains in literature are more intelligent than the heroes. & 1.42 & 0.643 \\
(7) Literature gives us food for thought. & 1.61 & 0.701 \\
(8) Literature contains moral lessons. & 2.22 & 0.680 \\
(9) The heroes in films are simply lucky. & 1.35 & 0.662 \\
(10) Literature does not benefit us in any way. & 1.13 & 0.448 \\
(11) The villains in books are more interesting. & 1.62 & 0.728 \\
(12) The stories are all similar. & 1.54 & 0.662 \\
(13) In literature, I prefer the heroes to be imaginary beings. & 1.72 & 0.760 \\
(14) I would like to be like the heroes in books. & 1.85 & 0.795 \\
(15) Literary heroes in no way resemble reality. & 1.70 & 0.766 \\
(16) I would prefer it if the good guy didn't always win in literature. & 1.68 & 0.744 \\
(17) Literature is more for adults. & 1.23 & 0.490 \\
(18) Literature gives us knowledge. & 2.42 & 0.690 \\
(19) I laugh a lot with books. & 1.92 & 0.589 \\
(20) I want to do whatever I read in books. & 1.66 & 0.762 \\
(21) I want the bad guys to become good in the end. & 2.20 & 0.786 \\
(22) I like books that have imaginary countries. & 2.04 & 0.735 \\
(23) I want the heroes in books to all be children. & 1.42 & 0.643 \\
(24) My friends and I make believe that we are heroes from books. & 1.40 & 0.589 \\
(25) At carnival, I dress up as the hero or heroine of my favourite book. & 1.44 & 0.661 \\
(26) I am tired of children's books. & 1.49 & 0.752 \\
(27) I want an animal just like the one my favourite hero or heroine has. & 1.70 & 0.738 \\
\hline
\end{tabular}

In Table 3 above, the statements which caused strong disagreement among the children are that literary books are naïve, underestimate children and do not benefit them in any way. The statements with which they particularly agree are that literature contains moral lessons, is always on the side of the good guy and imparts knowledge, and that children would like the bad guys to become good in the end. Furthermore, boys laugh more $(37.8 \%)$ than girls $(7.7 \%)$ with literature; girls like books that have imaginary countries (42.3\%), while boys do not like such books that much (13.3\%); girls are not tired of books (76.9\%), compared with boys (53.3\%); and more boys (60\%) than girls (34.6\%) want an animal just like the one their favourite hero or heroine has.

However, we note that: (a) children who read three or more books a month disagree (100\%) with children that do not read any books $(62.5 \%)$ that literature does not benefit them in any way, (b) children who do not read any books would all like to be like literary heroes $(100 \%)$, while only $16.7 \%$ of children who read three or more books want to be like these heroes, and (c) $62.5 \%$ of children who do not read any books totally agree that literary heroes do not resemble reality in any way, while children who read one book a month do not agree so wholeheartedly $(6.9 \%)$.

Some additional observations regarding the villains identified are that: (a) the villains are male (83.8\%) rather than female $(16.2 \%)$, (b) the chosen villains are older than the children $(73.2 \%)$, (c) the villains are human beings $(81.4 \%)$ rather than animals $(18.6 \%)$, (d) most of the villains are poor $(74.7 \%)$ rather than rich $(25.3 \%)$, (e) the villains come from other countries $(56.6 \%)$ rather than Greece $(43.5 \%)$, (f) the villains are mainly from books $(82.0 \%)$ rather than television $(18.1 \%),(\mathrm{g})$ the villains with a different cultural identity are more frequent $(57.7 \%)$ than villains who are Christian Orthodox (42.3\%), and (h) the villains have natural powers $(50.6 \%)$ rather than evil powers $(5.6 \%)$.

Furthermore, children: (a) prefer heroes (98.1\%) to anti-heroes (1.9\%) in the books they read, (b) prefer imaginary $(69.2 \%)$ to real heroes $(30.8 \%)$, (c) prefer to read novels $(65.7 \%)$ and illustrated books $(24.8 \%)$ to general narratives $(7.6 \%)$ or adaptations, (d) read age-appropriate books $(87.9 \%)$ rather than books for older readers $(12.1 \%)$, (e) choose books that are serious (73.8\%) rather than humorous $(26.2 \%)$, (f) prefer books by foreign authors (58.5\%) to books by Greek authors $(41.5 \%)$, $(\mathrm{g})$ prefer books that have been written to be published as such $(86.9 \%)$ to books that were initially films and were then made into books (13.1\%).

\section{Discussion}

The main objective of this research, which took the form of a case study, was to explore the assessments and evaluations made of heroes in children's literature. The analysed data were presented in the above section and demonstrated that children read children's literature and can make value judgements about their preferred heroes. 
However, an interesting and challenging aspect that arose from our research is the children's inability to clearly categorise certain characters (namely, as heroes or villains), which led to their placement in a new category, which defines a character as both a hero and villain in the same story (for example, the Wolf is good and bad). Of course, in modern stories, the Wolf is sometimes good and sometimes bad, as opposed to earlier fairy tales, in which he was always bad (for example, in Little Red Riding Hood).

The multiple, unclassified, associated meanings anchored to the concepts hero and villain are of particular interest in this study. Obviously, every sign, in this case the hero or villain, can have an associated meaning, or a large number of associated meanings, and can even share some or all of them with other signs. However, the 'elasticity' of the concept of association is functionally determined when the sign is placed within a certain context (Boklund-Lagopoulou, 1980: 207), e.g. the hero in children's literature. Thus, given that in this study the anchorage for the concepts associated with heroes or villains concerns children of the same age group (and that the children have been exposed to the same texts, more or less), we assumed that there would be a clear demarcation between heroes and villains ${ }^{11}$ on the children's part. The question thus arises whether children ultimately do not have such clear-cut conceptions of what is good and what is bad, but instead recognize that a bad character can also have good aspects and vice versa.

The study showed that there are a number of characters that have been classified as both heroes and villains, a fact which the researchers felt to be rather odd, leading them to put forward some tentative ideas for future exploration (see Gash, and Conway, 1997).

One would expect that, based on socio-semiotic theory, the context would provide for a clearer demarcation between the semantic opposites hero and villain. We know that in literary narratives, associated meaning is largely conscious (since it is 'imposed' by the author), so that only a small number of associated codes dominate, thus influencing the reader in one direction only (Boklund-Lagopoulou, 1982).

However, the children's responses did not reveal what was expected, that is, readings with a relatively distinct demarcation between heroes and villains. Instead, there is a certain confusion on the part of children, which tends to neutralize the concepts hero and villain and to present a character without distinct semantic loads or internalized — on the part of the researchers - conflicting relationships, e.g. good versus bad. Consequently, Barbie, Batman, Jack Sparrow, Superman, Tweety, Lucky Luke and the Wolf become part of a new category that consists of two conflicting concepts, hero and villain.

The above observation led the researchers to think that the emphasis placed on the modern-day hero in literary or other narratives mainly concerns their physical traits [what (s)he can or cannot do] rather than their mental attributes and beauty (that is, values and ideals). Thus, based on this analysis, a character's abilities (e.g. Harry Potter can do magic) turns them into something new, namely someone who is both a hero and a villain. This observation in a way indicates that the narratives of many children's books are not structured around the known conflicting semantic loads. It suggests that there is a new ideological sphere that corresponds to that of the socioeconomic context in which they function. It is thus no coincidence that children are confused in this matter; it is a reflection of the ideology that society wants to generate, namely unclear and undefined standards of what is good and what is bad, and a mixed type of hero that embodies both (White, \& O’Brien, 1999; Simmons \& Wade, 1983).

\section{References}

Applebee, A. (1978). The child's concept of story: Ages two to seventeen. Chicago: The University of Chicago Press.

Bardin, L. (1989). L' analyse de contenu. Paris: Presses Universitaires de France.

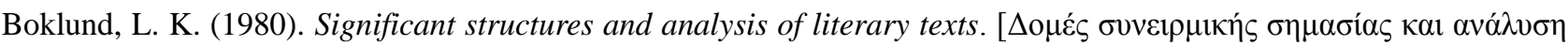

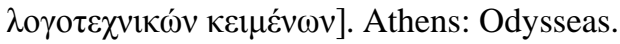

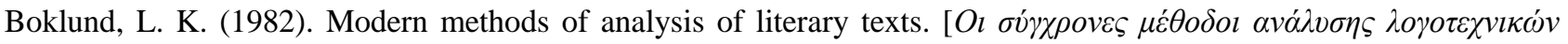

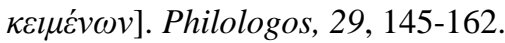

Brunel, P. (1992). Companion to Literary Myths, Heroes and Archetypes. New York: Routledge.

Campbell, J. (1968). The Hero with a Thousand Faces. Princeton: Princeton University Press.

Duck, J. (1990). Children's ideals: The role of real life versus media figures. Australian Journal of Psychology, 42(1), 19-29. http://dx.doi.org/10.1080/00049539008260102

Fisher, W. R. (1989). Clarifying the Narrative Paradigm. Communication Monographs, 56(1), 55-58.

\footnotetext{
${ }^{11}$ It is important to remember that the characters were assessed as being good or bad, i.e. heroes or villains, based on four categories of analysis, namely (a) beauty, (b) abilities, (c) mental attributes and (d) physical attributes.
} 
http://dx.doi.org/10.1080/03637758909390249

Fisher, W. R. (1985a). The narrative paradigm: An elaboration. Communication Monographs, 52(4), 347-367. http://dx.doi.org/10.1080/03637758509376117

Fisher, W. R. (1985b). The Narrative Paradigm: In the Beginning. Journal of Communications, 35(4), 74-89. http://dx.doi.org/10.1111/j.1460-2466.1985.tb02974.x

Franz, M. L. von. (1997). Archetypal Patterns in Fairy Tales. Toronto: Inner City.

Galani, A., \& Kyridis, A. (2005). The movie, kind of fun, communication or training? Children's views on children's

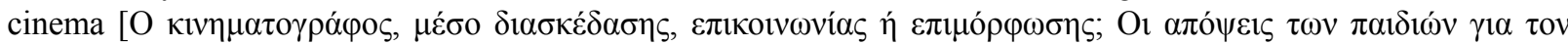

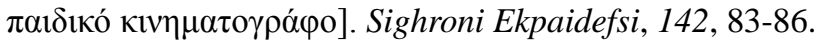

Galani, A., \& Kyridis, A. (2005). I like Pocahontas because it is beautiful despite being Indiana. [Mov $\alpha \rho \varepsilon ́ \sigma \varepsilon ı ~ \eta$

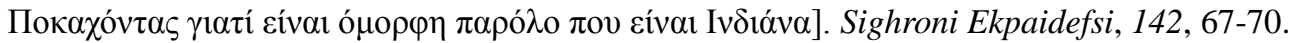

Gash, H. \& Conway, P. (1997). Images of heroes and heroines: How stable. Journal of Applied Developmental Psychology, 18(3), 349 - 372. http://dx.doi.org/10.1016/S0193-3973(97)80005-6

Gavriilidou, S. (2002). The child and the teenager in the works of Beatrice Solinas Donghi, Bianca Pitzorno, Marcello

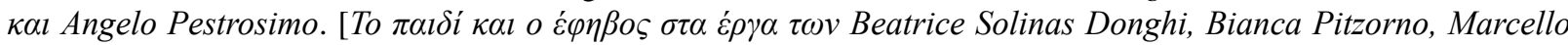
кal Angelo Pestrosimo]. Unpublished doctoral thesis, Aristotle University of Thessaloniki.

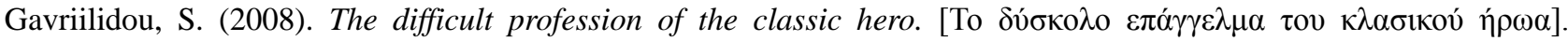
Thessaloniki: University Studio Press.

Gkolia, P., \& Kyridis, A. (2008). From Alexander the Great and Kolokotronis, to the National Team in E. Paparizou and

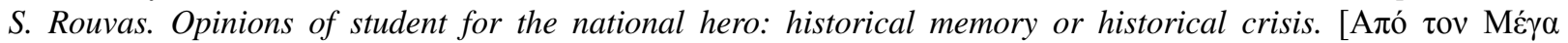

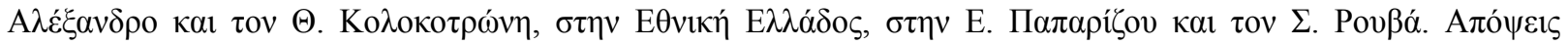

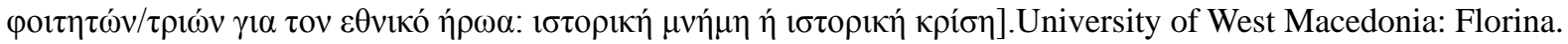

Greimas A. J. (1966). Sémantique Structurale. Paris: Larousse.

Halliday, M. A. K. (2004). In J. Webster (ed). Early Childhood. New York: Continuum.

Hogan, P. (2004). The Mind and Its Stories: Narrative universals and human emotions. Cambridge: Cambridge University Press.

Huck, C., Hepler, S., Hickman, J., \& Kiefer, B. (2001). Children's literature in the elementary school $\left(7^{\text {th }}\right.$ ed.). New York: McGraw Hill..

Jones, D., \& Watkins, T. (2000). Introduction. In Jones, D., Watkins, T. (ed.) A Necessary Fantasy? The Heroic Figure in Children's Popular Culture. New York: Garland, 1-19.

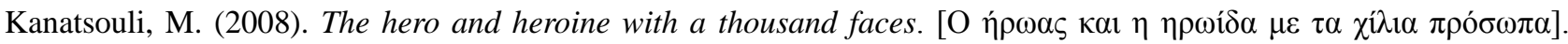
Athens: Gutenberg.

Knapp, B. L. (2003). French Fairy Tales: A Jungian Approach. Albany: State U. of New York.

Kouraki, C. (2008). Narrative and literary characters. The faces in the fictional prose of Georges Sari (1969-1995).

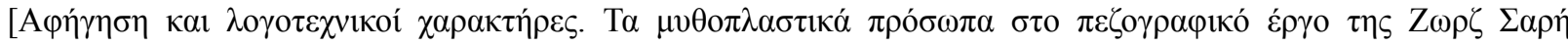

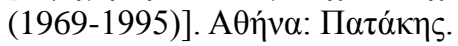

Lockwood, P., Jordan, C. H., \& Kunda, Z. (2002). Motivation by positive or negative role models: Regulatory focus determines who will best inspire us. Journal of Personality and Social Psychology, 83(4), 854-864. http://dx.doi.org/10.1037/0022-3514.83.4.854

Lockwood, P., Sadler, P., Fyman, K., \& Tuck, S. (2004). To do or not to do: Using positive and negative role models to harness motivation. Social Cognition, 22(4), 422-450. http://dx.doi.org/10.1521/soco.22.4.422.38297

Martin, J. (2007). Children's attitudes toward superheroes as a potential indicator of their moral understanding. Journal of Moral Education, 36(2), 239 - 250. http://dx.doi.org/10.1080/03057240701325381

Moscovici, S. (1970). La psychanalyse, son image et son public. Paris: PUF.

Mucchieli, R. (1988). L'analyse de contenu des documents et des communications. Paris: Les Editions ESF.

Neuendorf, K. (2002). The Content Analysis Guidebook. Thousand Oaks, CA: Sage Publications. 
Nikolajeva, M. (2002). The Rhetoric of Character in Children's Literature. Lanham, Maryland \& London: The Scarecrow Press, Inc.

Nodelman, P., \& Reimer, M. (2003). The pleasures of children's literature (3rd ed.). Boston: Allyn \& Bacon.

Papantonakis, G., Athanasiadis, E., Kaplanoglou, M., \& Politis, D. (2010). Children's ideas about children's literature.

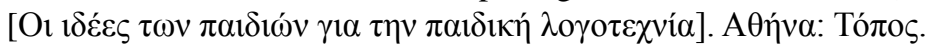

Phelan, J. (1989). Reading people, reading plots: character, progression and the interpretation of narrative. Chicago: University of Chicago Press.

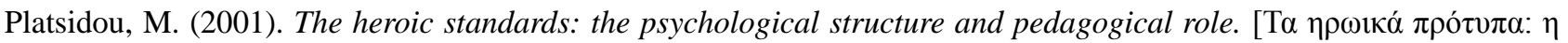

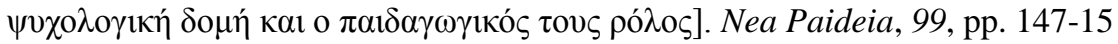

Simmons, C. V., \& Wade, W. B. (1983). The young ideal. Journal of Moral Education, 12(1), 18 - 32. http://dx.doi.org/10.1080/0305724830120103

Sloan, G. (1991). The Child as Critic. New York: Teachers College.

Weber, R. P. (1990). Basic Content Analysis. Newbury Park, California: Sage Publications.

Wells, G. (1986). The meaning makers. Portsmouth, NH: Heinemann.

White, S. H. (1999). What is a hero? An explanatory study of students' conceptions of heroes. Journal of Moral Education, 28(1), 81-95. http://dx.doi.org/10.1080/030572499103322

\section{(cc) $\mathrm{BY}$}

This work is licensed under a Creative Commons Attribution 3.0 License. 